\title{
THE ROLE OF EXTERNAL KNOWLEDGE IN THE INNOVATIVE ACTIVITIES OF AGRICULTURAL BIOTECHNOLOGY MULTINATIONALS
}

\author{
Fernanda Teixeira Franco Ribeiro ${ }^{1}$, Mariane Figueira \& Cristina Lelis Leal Calegario \\ Universidade Federal de Lavras - UFLA, Minas Gerias, (Brasil)
}

\begin{tabular}{l}
\hline ARTICLE DETAILS \\
\hline Article history: \\
Received: 21 May 2020 \\
Accepted: 07 July 2021 \\
Available online September: 01 th 2021 \\
Double Blind Review System \\
Scientific Editor \\
Ilan Avrichir \\
\hline Keywords \\
Innovation; \\
Patents; \\
Multinational Companies; \\
Innovative Scale
\end{tabular}

\begin{abstract}
Objective: To evaluate the influence of external knowledge absorbed on the potential to innovate of multinational companies (MNCs), in the genetically modified (GM) seed sector from 2000 to 2018.
\end{abstract}

Method: A quantitative approach was applied. Data was composed of the main patents filed by MNCs in the GM seed sector, collected from the Espacenet database, the MNCs' annual reports, and the INPI database. Variables were analyzed using panel regression model.

Main results: Results showed that the MNCs' own resources, as well as the external knowledge absorbed were individually significant. The Interactive variable was not significant in the model.

Relevance/ Originality: In addition to addressing literature gaps related for instance to the need to investigate the factors that influence the generation of innovation in multinationals, the present study focused on the agricultural biotechnology sector, which is of paramount importance for the innovations generated in agriculture.

Theoretical contributions: This study contributes by filling literature gaps related to the need to understand how important is the influence of the external knowledge and resources to the innovative capabilities of MNCs.

Social contributions: This paper helps managers be conscious of the fact that innovation is not only developed internally, involving the MNC's own network, but in fact, innovation requires relationships with other companies, allowing the access of external knowledge and resources.

\section{INTRODUCTION}

Innovation has been considered a key factor for companies, once it represents a source of knowledge and economic growth for both developed and developing countries (Neves, Afonso, Silva, \& Sochirca, 2021; Hossain, 2021; Chen, Liu, \& Ge, 2021).

According to Tidd, Bessant, and Pavitt (2005), innovation, 'something new and difficult to copy', leads the company to a position of competitive advantage. Granstrand and Holgersson (2020) explained that most definitions of 'innovation', understood as an outcome of a process, rest on two defining characteristics, a degree of newness of a change and a degree of usefulness or success in the application of something new, which could mean new to world, new to a nation, or new to a firm, for instance.

Multinational enterprises (MNEs) have been held largely responsible for the generation and diffusion of innovation (Papanastassiou, Pearce, \& Zanfei, 2020; Fu, Emes, \& Hou, 2021; Ha, 2021). These companies are viewed by international business scholars as superior in terms of technology and innovation development (Dunning, 2000; Caves 1974). According to perspectives proposed by different scholars, the innovative potential of multinational companies may be related to their greater probability

\footnotetext{
${ }^{1}$ Contato do autor - E-mail: fernandafrancoribeiro@gmail.com
} 
of entering new and more distant technological fields and volume spent on knowledge creating activities and technology-intensive products (lammarino \& McCann, 2013); the fact that MNEs represent the majority of global R\&D expenses and share their knowledge among international subsidiaries (GarcíaVega, Hofmann, \& Kneller, 2019); significant knowledge advantages, related to the access to widely dispersed knowledge and intra-firm knowledge flows (Zhang, Jiang, \& Cantwell, 2019); the fact that MNEs benefit from knowledge accessed through participating in both internal and external networks (Scott-Kennel \& Saittakari, 2020).

Even though many scholars sought to understand innovation in MNEs, it is still not very clear in the literature which factors impact the creation and development of innovative capabilities by those firms (Phene \& Almeida, 2008).

Among several highly innovative sectors, we highlight the agricultural biotechnology sector, specifically the genetically modified (GM) seed sector, which among other activities, modifies living organisms in order to obtain higher yields in crop production, through for instance, the development of crops which are resistant to pests and diseases (Montagu, 2020).

In the sector of genetically modified seeds there are a few active multinational companies. According to Silveira (2018), large global agribusiness companies have joined forces in recent years. In 2015 and 2016, a series of mergers and acquisitions took place in Brazil between large companies, such as the US companies Dow Agrosciences and Dupont, creating Corteva, the Chinese company ChemChina acquired the Swiss Syngenta, and Bayer acquired Monsanto. This company strategy can indicate the importance of external knowledge in complementing of what already exists in the company.

The present study seeks to understand the process of generating innovation in the genetically modified seed sector. This sector is believed to be quite appropriate for this investigation for the fact that it has clearly delivered an array of powerful innovative tools to medicine and agriculture (Montagu, 2020). According to Castro (2006), the need for innovation in the seed sector is constant and most innovations, researched or commercialized, are developed by large foreign companies seeking partnerships in different countries to access a variety of technical knowledge, such as crop information and adaptations to climate and soil conditions, with a perspective of combining them to existing ones, to generate new, innovative and market-specific products and services.

Having in mind that the largest amount of innovation in the genetically modified seed sector is developed by multinational firms (Castro 2006; Montagu, 2020) and drawing on prior research in international business, such as the one developed by Phene and Almeida (2003), which calls attention to the fact that the technological knowledge of the multinational firm is both developed internally by the firm, through its own R\&D, but also acquired from outside the firm, this study intends to answer the following question: What are the factors that influence innovative activities of multinational companies operating in the genetically modified seed sector?

In this context, this study aimed at evaluating the influence of external knowledge absorbed on the potential to innovate of multinational companies (MNCs), in the genetically modified seed sector from 2000 to 2018.

Therefore this study intends to fill two literature gaps: understand those factors that influence the development of innovative capabilities of MNEs (Papanastassiou, Pearce, \& Zanfei, 2020; Phene \& Almeida, 2008) as well as investigate an understanding in the field of international business which is the fact that knowledge which is capable of generating innovation in multinational firms comes from internal and external environments (ScottKennel \& Saittakari, 2020; Ferraris, Bogers, \& Bresciani, 2020; Almeida \& Phene, 2004; Cohen \& Levinthal, 1990).

In such a context, one of the main contributions of this study is related to deepening the understanding proposed by Phene and Almeida (2003), which stressed that knowledge used to innovate by the multinational firm is both acquired internally by the firm through its own R\&D, routines and resources, and also acquired from outside the firm (through knowledge that is accessed by partnerships, for instance). In that line of reasoning, this study brings a theoretical contribution as it intends to examine if multinational companies' characteristics, such as experience and investments in R\&D, as well as external knowledge available to the firm affects innovation. 
Another contribution of this study is related to understandings that external knowledge influences innovation in subsidiaries of multinational firms, having in mind they are simultaneously embedded in two knowledge contexts: (a) the internal multinational corporation (MNC) comprised of the headquarters and other subsidiaries; and (b) the external environment (Almeida \& Phene, 2004; Ferraris, Bogers, \& Bresciani, 2020), and the understanding that internal and external knowledge sources may influence the absorptive capacity access, and utilization of knowledge- of multinational firms (Cohen \& Levinthal, 1990; Phene \& Almeida, 2008).

Considering this paper's contribution to management, it is relevant to note that this paper helps managers be conscious of the fact that innovation is not only developed internally, involving the multinational's own network, but in fact, innovation most of the time, requires relationships with other companies, allowing the access of external knowledge and resources (Crespo, Lages, \& Crespo, 2020; Ferraris et al. 2020).

This paper is divided into five parts. After the introduction, the next section presents our theoretical framework, as well as hypothesis. Section three presents the paper's methodological procedures. Section four presents results and discussion and section five the concluding remarks.

\section{THEORETICAL FRAMEWORK AND HYPOTHESES}

\subsection{Multinational Firms, Innovation and Absorptive Capacity}

Scholars have long seen multinational firms as the forefront on the pursuit of the knowledge-generating capabilities needed for technology and innovation development (Su, Kong, Ciabuschi, \& Yan, 2021). According to Birkinshaw and Hood (1998), multinational companies can be considered a broad global innovation network and the many resources that multinational companies have are sources of innovation (Powell \& Grodal, 2006). Following this line of reasoning, Crespo, Lages, and Crespo (2020) conceptualized the MNE as a network of multiple knowledge units, in which subsidiaries might act as critical knowledge hubs, capable of accessing, converting, and transferring knowledge throughout the entire network.
According to Mudambi (2004), it is widely recognized that a MNE is a differentiated network for having skills to create new knowledge and competencies. These authors outlined the evolutionary process by which MNEs moved from recipients of knowledge to strategic actors in the innovation process.

In this context, scholars have based their studies upon the knowledge-based view (KBV) of the firm, considering that this approach can be seen as relevant for understanding issues related to knowledge transfer, as well as access, accumulation, extension and development of competencies and resources necessary to enhance innovative processes (Paswan \& Panda, 2020; Ritala \& Stefan, 2021).

The knowledge-based view understands knowledge as a crucial asset for companies and as one of the main resources to create and sustain competitive advantage (Bender \& Fish, 2000; Landry \& Amara, 2012; McBeath \& Ball, 2012). It is worth noting that knowledge can be accessed both from the resources that the firm has developed throughout its history (Grant, 1997; Dost, Badir, Sambasivan, \& Umrani, 2020) as well as from the external environment (Gulati, 1999; Medasea \& Abdul-Basit, 2020). The same for multinational enterprises, innovative capabilities might be related to knowledge and capabilities developed both within and outside firm boundaries (Ferraris, Bogers, \& Bresciani, 2020; Hansen, Larsen, Bhasin, Burgers, \& Larsen, 2020).

In this context, Ferraris et al. (2020) integrated literature on open innovation which focuses on external sourcing of knowledge at the organizational level and international business which pays attention to subsidiaries' role in multinational firms' innovation activities, highlighting the relevance of subsidiaries' external and internal linkages to examine open innovation at the subsidiary level within MNCs. Through an empirical analysis using data from 91 MNC subsidiaries, the scholars found that openness of subsidiaries to external knowledge sources impact innovation performance. Nevertheless, they found that subsidiaries' internal embeddedness positively moderates the relationship between openness and innovation, indicating that MNCs' subsidiaries should develop mechanisms to manage intra-organizational relations in order to achieve improved innovation performance while leveraging external knowledge sources at the subsidiary level, favoring MNCs' knowledge management approach. 
Besides external knowledge sourcing, learning is also a relevant factor for multinationals, as can be seen in the study developed by Hansen et al. (2020), which by focusing on the dynamics of learning and innovative capability development over time within individual MNC subsidiaries, developed a case study with an in-depth analysis of the innovation capability development trajectory of a local subsidiary of a Danish first-tier supplier of wind turbine blades. The scholars emphasized the key role of the parent company and internal learning in the subsidiary as the basis for the advanced level of innovation capabilities achieved by the subsidiary, enabling it to become a supplier of innovations to its parent company.

While the internal and external knowledge of the firm are important sources for the generation of innovation, the use of knowledge depends on the capabilities, or the so-called absorptive capacity of the firm, which can be considered one of the key aspects of the knowledge-based view (Phene \& Almeida, 2008). According to Cohen and Levinthal (1990), the absorptive capacity of an organization depends on the individual capacities of its members, and is built based on the organization's previous investment in individual absorptive capacities, and as well as the individual absorptive capacity, the organizational absorptive capacity tends to develop cumulatively. According to the scholars, the organizational absorptive capacity is not a sum of the individual capacities of its employees, but the organization's ability to access, assimilate and explore information.

Cohen and Levinthal (1990) also explained that the absorptive capacity is to a large extent, a function of the firm's prior knowledge related to external knowledge. According to the scholars, the firm's prior knowledge consists of basic skills, or even a shared language, but it also includes knowledge of the most recent technological or scientific developments in a given area. In addition to that, the absorptive capacity, which is cumulative, also depends on the firm's historical trajectory.

The firm's absorptive capacity can be defined as an organization's ability to recognize and assimilate the value of new external information and apply it for commercial purposes (Cohen \& Levinthal, 1990). Cohen and Levinthal (1990), in addition to emphasizing that external knowledge is a critical element for innovation in the firm, have also argued that absorptive capacity is fundamental for the formation of innovative capabilities.

The capabilities of firms began to receive greater attention with the research of evolutionists such as Nelson and Winter (2005). Nelson and Winter (2005) developed the evolutionary theory of economic change precisely to explain how firms' capacities and behavior evolve, enabling the creation of new processes, products, and innovation. According to the scholars, firms can be understood as living organisms. Drawing on the biological evolutionary theory Nelson and Winter (2005) explained how firms, through their 'routines', have the ability to be selected from those that will be victorious and continue to operate in the market.

These routines, as the scholars emphasized, are all the regular and predictable behavioral patterns of firms, including the characteristics of firms, such as well-structured technical routines for the production of products; procedures for hiring and firing employees; new inventory orders; policies related to investment in R\&D or advertising; production diversification strategies; and even, investment abroad.

Drawing on the evolutionary theory of the firm, it is possible to infer that firms evolve throughout time and become more capable of developing their absorptive capacity and innovative activities.

\subsection{Investments in R\&D and MNC's Innovative Activities}

Investments in knowledge and R\&D play a fundamental role in the development of new capabilities and innovation. By doing so, firms which invest more intensively in R\&D activities are more likely to develop innovations, such as products, processes, or patents (Crespi \& Zuniga, 2012).

Nevetheless, MNCs are expected to develop independent innovations and skills gradually (Almeida \& Phene, 2004). Over time the firm's innovative activities are expected to increase. As MNCs mature, they are expected to gradually engage in an expansion of their research agenda through exploratory activities encompassing dominant technologies- which have one main feature that can derive other innovations (Granstrand, Patel, \& Pavitt, 1998). In this context, MNCs evolve in the way they 
access and use knowledge and over time, they acquire more knowledge (Phene \& Almeida, 2008).

In such a context, Figueiredo, Larsen and Hansen (2020), willing to understand how subsidiaries create technological capabilities to innovate in emerging economies, developed a single-case study of a Brazilian subsidiary of a large biotechnology MNE (1989-2016). The authors found that the subsidiary's technological capability-building, from productionbased to advanced levels (including R\&D for applied research), reflects the effectiveness with which it implemented interactive learning strategies through the use of 'science, technology and innovation' (STI) and 'doing, using and interacting' (DUI) learning mechanisms to tap into three types of knowledge sources: within the subsidiary, the MNE corporate network, and other host sectoral system organizations. The scholars also found that the effectiveness of these strategies related to the combined use of various STI/DUI mechanisms over time, supported the technological capability-building process, as well as the implementation of innovation activities with increased value and novelty.

Another aspect worth mentioning is that the role of R\&D investments may differ among sectors in terms of time necessary to achieve the innovation. Considering diverse sectors, researchers have found that in terms of published patents, the effect may not be seen immediately. Sierotowicz (2015) evaluated the efficiency of $R \& D$ expenditure from the patent activity in 28 European Union (EU) countries for the period 1999-2013 and concluded that there was a significative increase in total expenditure on $R \& D$ activities in the business enterprise sectors of the ten leading EU countries and an increase in the patenting activity of the sector in the long run.

Altuzarra (2019) provided empirical evidence on the link between firms' R\&D expenditure and patent registrations in a panel of Spanish manufacturing firms for the period 1990-2013.

Consistent with these and considering the genetically modified seed sector, we posit the following:

Hypothesis 1. Investments in R\&D have a positive influence on the MNC's innovative activities.
2.3 External Knowledge and MNC's Innovative Activities

According to Almeida and Phene (2004), although the company's own research efforts play an important role in innovation, external sources of knowledge are essential for the innovative capacity, thus increasing the ability to recognize and assimilate new technological knowledge, influencing the innovative potential of the firm. Phene and Almeida (2008), also emphasized that knowledge, which is important for the generation of innovation, can be obtained both from the resources that the firm has developed throughout its history, as well as from the external environment.

For instance, Un and Rodríguez (2018) analyzed how R\&D collaborations affect product innovation for subsidiaries of multinationals and domestic firms. The scholars proposed that subsidiaries may benefit more from undertaking R\&D collaborations with customers and competitors, who have deeper knowledge of local conditions, better complementing the global knowledge base of subsidiaries.

It seems that input companies can no longer afford to rely solely on their own R\&D organizations for the most promising innovations, especially in areas outside their traditional purview. Instead, they need to enrich their innovation pipelines by working with other specialized companies. The external ecosystem of biotech and agricultural-technology startups is by no means as rich as that of, say, the pharmaceutical industry, but it is gaining momentum quickly (Kurth, Möller, Jerratsch, Adolphs, Wübbels, \& Walker, 2020).

Therefore, it can be expected that external knowledge absorbed from relationships with other firms in the sector, even if from countries other than the country of origin, such as via foreign subsidiaries, positively influences MNCs innovative activities over time, since they gain experience, accumulate knowledge and expertise.

Thus, we posit the following:

Hypothesis 2. External knowledge absorbed has a positive influence on the MNC's innovative activities.

\subsection{The Moderating Effect of External knowledge}

In the agricultural technology industry, companies present different levels of knowledge intensity as is 
the case with multinational companies obtaining biotechnology with patents (Carayannopoulos \& Auster, 2010). The reason for that, may be not only because of owned characteristics as size, and experience, but also for its strategy of expansion.

Most companies in this sector, to develop traits (or transgenic events), have large research and development programs in the discovery and evaluation of new genes that can be used in plants to give them desirable characteristics. However, other companies, besides this high level of R\&D investments, grew the corporation to vertically integrate industries, through acquisitions, joint ventures and strategic alliances. For instance, an agreement between Monsanto and BASF spent up to $\$ 1.5$ billion on engineering stress-tolerant corn, soybeans, cotton, and canola, for which the two companies currently control almost half the patents (Howard, 2009).

Therefore, innovating in the field of agricultural biotechnology is a complex process, involving high costs and cumulative and fragmented knowledge owned by different actors. Silveira, Dal Poz, Massago, and Campos (2011), observed that there is no reason to believe the naive assumption that from an extensive scientific base, originated with the discovery of DNA, there is the possibility of creating a radically innovative product without the integration between agents at the same time, throughout the process to generate a product from agricultural biotechnology.

Hence, multinational firms with higher investments in R\&D, either due to its expansion strategy or internal growth, are likely to develop competencies to absorb external knowledge for exploiting innovation advantages, which may be applied to develop patents. Consistent with these, and in order to understand the interactive effect of the MNC self-knowledge, that can be accessed from the resources that the firm has developed throughout its history, represented in this study by investments in $R \& D$, versus collaborated absorbed external knowledge from the environment, the moderate effect is measured.

As a net result, we expect environmental knowledge absorbed to increase the company's R\&D intensity and consequently the innovative activity of the firm.

Thus, we posit the following:
Hypothesis 3. External knowledge absorbed strengthens the positive effect of investments in R\&D on the MNC's innovative activity.

\section{METHODOLOGICAL PRODEDURES}

\subsection{Research Sample}

The research sample consists of the main multinational companies' patents in the genetically modified seed sector. The GM seed sector is a highly innovative and rapidly expanding industry that plays a prominent role in industrialized economies (World Intellectual Property Report, 2019).

The main companies operating in the GM seed sector are: Basf, Bayer CropScience, Dow Agrosiences, Dupont/Pioneer, Monsanto and Syngenta. The data collection period was from 2000 to 2018. It is worth mentioning that the analyzed period was chosen considering that the first patent registration of GM seeds was in 1998. As there was no patent registration for all the companies studied from 1998 till 2000, analysis was possible for the period from 2000 to 2018.

Data was collected from patents for genetically modified seeds of cotton, corn and soybean crops, as well as patents related to the creation of these GM products, aiming to identify the potential of innovation of the multinational companies. Data was collected from the Espacenet database, the INPI database, and as well as the multinational companies' annual reports. And the software used for the panel model analysis was the free STATA statistical program version 14.1.

\subsection{Measures}

\subsubsection{Dependent variable}

MNC's Innovate Activities (Scale) - The modeldependent variable is measured by the patents' scale, represented in this research by the number of patents registered

that year by the multinational analyzed. Patent data was collected from the Espacenet database, and can be considered one of the key indicators used by researchers to evaluate innovation. It is worth mentioning that despite the fact that the extant literature proposes several indicators to measure a firm's innovative performance, and the fact that the use of the number of patents has sometimes been 
criticized, being called a 'not perfect indicator' (Dosi, 1982), patent analysis provides key information to executives in charge of research and development, technological policies or technological strategy, specifically within the biotechnology sector (Pereira, Da Silva, Lavoie, \& Porto, 2018).

\subsubsection{Independent variables:}

Investments in R\&D (I R\&D) - represent the amount of how much companies invest in R\&D in the $t-1$ year. Data was collected from the multinational companies' annual reports. For most studies, R\&D expenditure in the agricultural sector is only one of the inputs that can derive innovation (Manogna, Mishra, \& Sinha, 2020). Indeed, it is particularly high in such industries as they include a large number of R\&D service firms such as biotechnology (Nagaoka, Motohashi, \& Goto, 2010).

External knowledge absorbed (Cited Pat) refers to the number of patents filed by other companies that the MNC used to create its own patent. A binary variable was created, where $D=0$, if the company did not use other patents to generate its own, and $D=1$ if the company used one or more patents. The idea was not to quantify the number of patents used in its own creation, but whether there was a need to use knowledge external to the company. Data was collected from the Espacenet database.

There are a number of studies using the citation as a measure of knowledge spillover, although there is a significant variation of the frequency of citations of science literature by technology sectors. However, its use is especially high in the biotechnology sector, reflecting the differing impact of science on technology. Citation information has been found to provide very useful information on the value of patents (Nagaoka et al. 2010). This variable shows that the more citations the MNC used, the more external knowledge it sought, since patent citations have been a relevant measure of knowledge transfer and innovation. On the other hand, the smaller this number is, the more self-knowledge the MNC uses.

Moderating Variable - represents the interaction effects that may occur between external knowledge absorbed and investments in R\&D variables when the effect of one variable depends on the value of another variable. Interaction effects indicate that a third variable influences the relationship between an independent and a dependent variable (Gujarati,
2012). It is expected to capture, besides the individual effect of this variable in the model, also the moderating effect to capture the strengthened MNCs' innovative activities when external knowledge is used.

\subsubsection{Control Variables:}

Net sales in agriculture (Sales Agr) - represents the percentage of all sales referring to the agricultural sector of companies in relation to net sales in the $t-$ 1 year. Data was collected from the multinational companies' annual reports. The more profitable these sales are expected to be, the greater is the firm's interest in generating more innovation and patents the next year.

Experience (Firm Exp) - represents the operating time of the company. Data also was collected from the multinational companies' annual reports. Phene and Almeida (2003) showed that the longer the company has operated in a certain market, the greater is its experience in that market, that is, the older the firm, the more knowledge it has, which will also allow it to engage in innovative activities.

Country Innovation (Country Innov) - represents the number of patents from all sectors filed in each country of origin of the multinationals, which may possibly help explain the potential of the country to innovate. We expect to have a control of the level of country development. This information was collected from the INPI database, referring to the multinational's host country.

\subsection{Data Analysis Techniques}

Data used and analyzed refers to the main patents filed by the main six multinational companies operating in the GM seed sector, namely: Basf, Bayer, Dow, Dupont, Monsanto and Syngenta, from 2000 to 2018. The most appropriate statistical method for achieving the proposed objectives was the panel regression model.

Greene (2008) defines panel data as a common term in statistics and its econometric applications can be used to designate information from various sample units, such as: individuals and companies, generally followed over time. The observations are considered in two extensions, one of them is the sampling unit and the other is the time, and the time 
can be replaced by other conditions of observation as different places.

Time-related information may be continuous or not. According to Greene (2008), data can be balanced when observations of all units are available over the entire period, or unbalanced panels when one or more units are not present in all periods of the database. In the present study, we have unbalanced data, so the most appropriate models for this situation are fixed effects models (FEMs) and random effects models (REMs).

FEMs, according to Greene (2008), are those in which the intercept varies between individuals and is constant over time, whereas regression coefficients remain as fixed constants for all individuals and at all time periods.

The general formula of fixed effect models is given by: $Y i=a i+\beta 1 X 1 i t+\beta 2 X 2 i t+\cdots+\beta k X k i t+u i t$ in which:

- $\quad Y i$ and $X i$ correspond to the observations of the dependent and independent variables, respectively, for unit i at time t;

- $\quad \beta$ refers to the regression parameters to be estimated and uit to the error term;

- $\quad a i$ is an unknown parameter to be estimated, being constant over time that captures differences between individuals, which may have their own characteristics that correlate between individuals.

According to Duarte, Lamounier, and Takamatsu (2007), when the intercept $\alpha i$ is correlated with the explanatory variables in any period of time, the fixed effect model is the best option.

The difference between the REM and the FEM would be the fact that the intercept is not treated as a fixed parameter but as a random variable (Wooldridge, 2011). The intercept is composed of the intercept that captures the differences of individuals and an idiosyncratic component.

According to Gujarati (2012), the REM is represented as follows: it $=\beta 0+\beta 1 X 1 i t+\beta 2 X 2 i t+$ $\cdots+\beta k X k i t+v i t$. The term vit refers to the error composed by the individual-specific error component $(\alpha i)$ which is a latent random variable, and may be correlated with the independent variables, and by the model error term (uit) that varies both according to the cut units as well as with time.
Both models have their advantages and disadvantages. According to Greene (2008), one of the advantages of REM stands out for incorporating individual differences in the error component. The fixed effect model, on the other hand, allows an indepth analysis of differences between individuals, is not biased when unobserved variables are correlated with explanatory variables, and presents better results when the sample is not a good representation of the population.

\section{RESULTS AND DISCUSSION}

In order to reach the objective of this study to evaluate the influence of external knowledge absorbed on the potential to innovate of multinational companies in the genetically modified seed sector, the fixed effects and random effects models were tested in order to obtain the best explanation for the relationship between variables.

Before proceeding with the analysis of the data in a panel model, a descriptive analysis of data was performed. In detail it could be inferred that the average of the scale in the period from 2000 to 2018, was approximately 16 patents, an average of US $\$ 146$ million for investments in research and development, $\$ 3$ million, as an average for net sales in agriculture, 105 years as an average for the experience of companies.

For the variable of the external knowledge absorbed, we have an average of approximately 14 cited patents. Figure 1 illustrates that the external knowledge absorbed by Syngenta, Monsanto and Bayer showed significant growth in the initial years and later a drop. The multinational Dupont presents in 2005 and 2006 the highest number of citations throughout of its trajectory. The companies Dow and Basf have a small number of citations, compared to other multinational companies, noting that Dow presented its greatest number of citations in the year 2016.

The number of patents filed by country of origin of the multinational company in the agricultural biotechnology sector presented an average of 4101,956 thousand units of patents filed. Figure 2 represents the number of patents filed per country of origin of the EMN. The German companies Basf and Bayer, the Swiss, Syngenta and the American companies Dow, Dupont and Monsanto lead the ranking. 
Table 1 presents the descriptive statistics of the variables in the model, the variance inflation factor (VIF) and the correlation analysis that was performed in order to confirm that the variables were used correctly. There are no values greater than $60 \%$ between the variables, and no values exceed 5 for the VIF.

Table 1 Descriptive Variables and Correlation between proposed variables

\begin{tabular}{l|c|c|c|c|c|c|c|c|c|c|c|c}
\hline & Scale & I R\&D & Sales Agri & Firm Exp & $\begin{array}{c}\text { Cited } \\
\text { Pat }\end{array}$ & $\begin{array}{c}\text { Filed } \\
\text { Patents }\end{array}$ & Obs & Mean & SD & Min & Max & VIF \\
\hline Scale & 1 & & & & & & 98 & 16.18 & 26.67 & 1 & 150 & 1.92 \\
\hline I R\&D & 0.004 & 1 & & & & & 114 & 146.03 & 289.37 & 1.032 & 969.000 & 2.81 \\
\hline $\begin{array}{l}\text { Sales } \\
\text { Agri }\end{array}$ & 0.335 & 0.596 & 1 & & & & 114 & 3.196 & 2.689 & 0.055 & 1 & 1.94 \\
\hline $\begin{array}{l}\text { Firm } \\
\text { Exp }\end{array}$ & -0.265 & - & -0.428 & 1 & & & 114 & 105.66 & 71.32 & 18 & 216 & 1.13 \\
\hline $\begin{array}{l}\text { Cited } \\
\text { Pat }\end{array}$ & -0.104 & 0.092 & 0.062 & 0.018 & 1 & & 98 & 14.18 & 37.22 & 0 & 1 & 2.70 \\
\hline $\begin{array}{l}\text { Coun } \\
\text { try } \\
\text { Innov }\end{array}$ & 0.103 & - & -0.240 & 0.139 & 0.050 & 1 & 114 & 4101.9 & 3142.6 & 86 & 10267 & 3.54 \\
\hline
\end{tabular}

Source: Research Data Note: Scale (Unit of Measure: units); Investment in R\&D (Unit Measure: millions of dollars); Net Sales in Agriculture (Unit of Measure: millions of dollars); Experience (Unit of Measure: years); Cited Patents (Dummy Variable, Unit of Measure: unit); Country Innovation (Control Variable, Unit of Measure: unit).

According to Greene (2008), besides the applied tests, one of the advantages of using panel models is that it reduces the presence of multicollinearity. Kmenta (1971) stated that panel data models have low values for $R^{2}$ and multicollinearity is a problem of the sample and not of the population.

To obtain the best explanation for the relationship between the variables, the fixed effect and random effect models were performed considering the hierarchical regression (as displayed on table 2). To decide which model to use, it was necessary to perform the Hausman test. (Croissant \& Millo, 2008). The Hausman test focuses on comparing the two estimators (fixed and random) under the null hypothesis that there is no significant difference, and if this is not rejected, the random effects estimator is chosen. For the present work, the hypothesis was not rejected, so the estimator chosen was the random effect.

The variables were inserted in the model in three hierarchical equations: Equation 1 consisted of all the variables in the model, except the Cited Pat; Equation 2 , all the variables in the model, and Equation 3, in addition to all the variables, it was also inserted the moderating variable, formed by the interaction of the latter with the Investment in R\&D. 
Table 2 Random Effects Model Panel Regression Results for Scale of Patents

\begin{tabular}{|c|c|c|c|c|c|c|}
\hline & $\begin{array}{l}\text { Equation } 1 \\
\text { Coeficient }\end{array}$ & $\begin{array}{c}Z \\
(P>|z|)\end{array}$ & $\begin{array}{c}\text { Equation } 2 \\
\text { Coeficient }\end{array}$ & $\begin{array}{c}Z \\
(P>|z|)\end{array}$ & $\begin{array}{l}\text { Equation } 3 \\
\text { Coeficient }\end{array}$ & $\begin{array}{c}Z \\
(P>|z|)\end{array}$ \\
\hline I R\&D & $-0.036 * * *$ & $\begin{array}{c}-3.69 \\
(0.000)\end{array}$ & $-0.033 * * *$ & $\begin{array}{c}-3.24 \\
(0,002)\end{array}$ & $-0.031 * *$ & $\begin{array}{c}-3.19 \\
(0.001)\end{array}$ \\
\hline Sales Agr & 26.128 & $\begin{array}{c}1.44 \\
(0.211)\end{array}$ & $44.818 * * *$ & $\begin{array}{c}3.88 \\
(0.000)\end{array}$ & $46.353 * * *$ & $\begin{array}{c}3.85 \\
(0.000)\end{array}$ \\
\hline Firm Exp & -0.092 & $\begin{array}{c}-1.22 \\
(0.236)\end{array}$ & -0.053 & $\begin{array}{c}-1.41 \\
(0.166)\end{array}$ & -0.052 & $\begin{array}{c}-1.25 \\
(0.211)\end{array}$ \\
\hline Country Innov & $0.002 *$ & $\begin{array}{c}1.73 \\
(0.049)\end{array}$ & $0.001^{*}$ & $\begin{array}{c}1.96 \\
(0.015)\end{array}$ & $0.002 *$ & $\begin{array}{c}2.07 \\
(0.038)\end{array}$ \\
\hline $\begin{array}{l}\text { Cited Pat } \\
\text { (Dummy) }\end{array}$ & & & $15.150 * *$ & $\begin{array}{c}2.73 \\
(0.006)\end{array}$ & $15.343^{* *}$ & $\begin{array}{c}3.14 \\
(0.002)\end{array}$ \\
\hline $\begin{array}{l}\text { I R\&D* Cited } \\
\text { Pat } \\
\text { (moderating } \\
\text { variable) }\end{array}$ & & & & & -0.000 & $\begin{array}{c}-1.13 \\
(0.262)\end{array}$ \\
\hline
\end{tabular}

Source: Research Data

$\mathrm{N}=98$; Number of companies $=6$

*** indicates significance at $1 \%,{ }^{* *}$ significance at $5 \%$ and $*$ significance at $10 \%$.

The first variable, Investments in $R \& D$, was confirmed to be significant in the three stages of the regression, but with a negative sign and this does not lead us to confirm that hypothesis $\mathrm{H} 1$ is true, showing that with each additional unit in research and development investment, the scale decreases by 0,03 units. Although this result does not confirm the theory that R\&D investments lead to an increase in the scale of innovation, it can be inferred in this case, where the innovative activity is being measured by the number of patents, that the coefficient, although negative, is exceedingly small, not totaling an entire unit of registered patent. We can also comment that for patent innovation it is necessary to wait for the result over time, that is, for investments in $R \& D$ to impact patent scale, it takes a certain amount of time, and in our case, we just lag by one year to not lose many observations (Nagaoka et al. 2010). On the other hand, Singh and Gaur (2013) suggest the use of output measures of innovation, such as the number of patents.

The Dummy variable, Cited Patents in the Equation 2, was significant, confirming the $\mathrm{H} 2$ hypothesis that external knowledge absorbed by MNCs positively influences innovative activity. This result shows that when the company uses knowledge developed from other companies (cited patents), the innovative scale increases by approximately 15 units, compared to when the company does not make any citations. Given the diverse resources of a company, knowledge is the most important strategic resource (Grant, 1996) and can provide opportunities for organizational renewal (Inkpen, 1998) and innovation implementation (Gilbert \& Hayes, 1996).

The moderating effect obtained by the interaction between I R\&D and Cited Patents was not significant. Therefore, hypothesis H3 was not supported. Our expectation was that the interaction effect between the independent variables could indicate that a third variable influenced the relationship between an independent and the dependent variable or in other words, as states Gujarati (2012), there may be an effect that is not simply additive, but multiplicative as well in the model. Based on that, the external knowledge absorbed by the MNCs, although positive and significant individually, has not moderated the 
specific potential of the company to strengthen MNCs' innovative activities.

For the control variables, we found that the variable net sales in agriculture was confirmed to be significant after being inserted into the Equations 2 and 3 , and it can be inferred that if net sales in agriculture increase by one unit, the scale increases by approximately 44 units.

The firm experience variable, which refers to how long the MNC has been established, was not significant in the three stages of the regression, which points to the fact that for multinational companies in knowledge intensive sectors, other factors have to be taken into consideration, such as the global focus, and strategies for expansion, involving foreign strategic partners not only to achieve sales abroad, but also access external knowledge sources, as well as the ability to recombine current knowledge for the development of new products (Sharma \& Blomstermo, 2003; Knight \& Cavusgil, 2009; Dourado, Figueira, \& Castro, 2019). Another fact worth mentioning is that all the knowledge intensive multinational firms operating in the genetically modified seed sector are experienced, where even a new company created by a merger occurred between two organizations has the historical trajectories of those firms summed (Rodrigues, 2018).

The country variable, number of patents filed in the countries of origin of the multinationals, was significant. We confirm that patent data, both applications and concessions, act as an intermediate result of innovative activity and provides insights about the company's innovative capabilities and its country (Organization for Economic Cooperation and Development [OECD], 2005).

All the results were relevant for a better understanding of a high technological sector, such as agricultural biotechnology. Although, the variable that measures the investments in R\&D made by companies has had a significant, but negative coefficient (albeit small), it is still reasonable to say that it is difficult for a company to generate patents without investing in research.

On the other hand, the citation of patents from other companies made a great contribution, both theoretical and managerial, reassuring the importance of the knowledge existing outside the company itself for its innovation.

\section{CONCLUDING REMARKS}

Motivated by the importance of innovation, in addition to studies that demonstrate the relevance of the innovative activities for MNCs, this study was developed willing to answer the question: What are the factors that influence innovative activities of multinational companies operating in the genetically modified seed sector?

For a better understanding, we incorporated theories that explore the role of the subsidiary in the generation of innovation, paying attention to knowledge which can be accessed externally, and the Knowledge Based View that provides support to understand the absorptive capacity of the firm and its use for innovation. The agricultural biotechnology sector seemed appropriated for the analysis, since in this sector the need for innovation is constant and most of the innovations in the seed industry researched and/or commercialized have been developed by large foreign multinationals which seek partnerships and alliances, leading us to acknowledge that external knowledge is relevant for these firms.

This study identified the main patents filed by the six multinational companies operating in the GM seed sector, namely: Basf, Bayer, Dow, Dupont, Monsanto and Syngenta, from 2000 to 2018 to analyze variables that might help answer the research question. In this context, the study's objective was to evaluate the influence of external knowledge absorbed on the potential to innovate of multinational companies (MNCS), in the genetically modified (GM) seed sector from 2000 to 2018.

Results showed that, besides the extant literature understanding which sees MNCs internal resources and knowledge as an important tool for innovating, in the case of the present study, the multinational firms' investments in R\&D did not influence positively the innovative activities of these firms. On the other hand, variables related to external knowledge such as number of patents filed in the country of origin, and the external knowledge absorbed in the form of cited patents were positive and significant. In other words, those firms among the multinationals which seek external knowledge are more innovative.

Results showed that the variable investments in $R \& D$, although significant, presented a negative sign, confirming that is possible to have a lag time necessary to evaluate the efficiency of R\&D expenditure on patenting activity and the positive 
results will happen in the long run. Then, it is very likely that it will take a certain period of time to observe the results of the company's innovative processes

The cited patent was significant and relevant for the increase of the innovative scale of the main companies operating in the sector worldwide. It can be said that the more the company absorbs external knowledge from other companies in the sector, the greater will their ability to innovate and consequently generate new products and processes be. Therefore, we show that cited patents by the MNCs operating in the genetically modified seed sector are a reasonable variable to measure external knowledge.

For the control variables, we found that the variable net sales in agriculture was confirmed to be significant, and it can be inferred that if net sales in agriculture increase by one unit, the scale increases by approximately 44 units.

The firm experience variable, which refers to how long the MNC has been established, was not significant, meaning it is very likely that in the biotechnological sector, we may find companies with a faster innovation growth independent from the operating time. Considering time experience, we also can say that all the firms have been a long time in the sector, even if they have changed names, as merged companies. The country variable, number of patents filed in the countries of origin of the multinationals, was significant, confirming that patent data might act as an intermediate result of firms' innovative activities.

Results obtained with this research might contribute to the understanding of the innovative capacity of MNCs in the agricultural biotechnology sector, specifically the genetically modified seed sector. In addition, it is believed that the research may guide actions towards the development of innovations in the sector of agricultural biotechnology by other companies, by clarifying the relationship between the firm's access to external knowledge and the possibility of generating future innovation.

One of the contributions of the present study is related to the fact that in addition to knowledge accessed internally, through research and development, it calls the attention of managers to seek and understand the process of accessing knowledge from outside the firm's boundaries, for example from their subsidiary companies around the world, or from other companies, which may also collaborate in building knowledge and innovation.

Another contribution of this study worth mentioning is the fact it addresses an avenue of research which discusses the real necessity of change in such an industry, as we have seen with the series of mergers and acquisitions process, keeping in mind that there is a possibility to get the intended knowledge from another large company.

It is also important to highlight the limitations of the present research. The first one is that we do not have available time data to apply a lag time more than one year to get the right effect of the R\&D investment in generating patents. Also, it can happen that the absorbed knowledge may come from companies that maintain informal inter-firm collaborations and we cannot capture all of that. It is worthy emphasizing that the variable used to measure the external knowledge absorbed is not recommended for analysis of sectors with less technological intensity, given the low application of patents. Yet our research still contributes to both theory and practice related to the role of external knowledge in the innovative activities.

A suggestion for future studies would be the use of other statistical techniques that allow further analysis around the theme or, also, the insertion of other variables for the selected population to measure for example, the company's absorptive capacity. Another suggestion would be applying this study to other sectors with high technological intensity and perhaps even carrying out comparative studies between different sectors.

\section{REFERENCES}

Almeida, P., \& Phene, A. (2004). Subsidiares and knowledge creation: influence of the_MNC and host country on innovation. Strategic Management Journal, 25(8-9), 847-864.

Altuzarra, A. (2019). R\&D and patents: Is it a two way street? Economics of Innovation and New Technology, 28(2), 180-96.

Bender, S., \& Fish, A. (2000). The transfer of knowledge and the retention of expertise- the continuing need for global assignments. Journal of Knowledge Management, 4(2), 125-137. 
Birkinshaw, J., \& Hood, N. (1998). Multinational subsidiary evolution: capability and charter change in foreign-owned subsidiary companies. Academy of Management, 23(4), 773-795.

Carayannopoulos, S., \& Auster, E. R. (2010). External knowledge sourcing in biotechnology through acquisition versus alliance: A KBV approach. Research Policy, 39(2), 254-267.

Castro, B. S. (2006). O processo de institucionalização da soja transgênica no Brasil nos anos de 2003 e 2005: a partir da perspectiva das redes sociais. Unpublished master's thesis, Universidade Federal Rural do Rio de Janeiro, Rio de Janeiro, Rio de Janeiro.

Caves, R, E. (1974). Multinational firms, competition, and productivity in host-country markets. Economica, 41(162), 176-193.

Chen, F., Liu, H., \& Ge, Y. (2021). How does integration affect industrial innovation through networks in technology-sourcing overseas M\&A? A comparison between China and the US. Journal of Business Research, 122(C), 281-292.

Cohen, W. M., \& Levinthal, D. A. (1990). Absorptive capacity: a new perspective on learning and innovation. Administrative Science Quarterly, 1(35), 128-152.

Crespi, G., \& Zuniga, P. (2012). Innovation and Productivity: Evidence from Six Latin American Countries. World Development, 40(2), 273-290.

Crespo, C. F., Lages, L. F., \& Crespo, N. F. (2020). Improving subsidiaries' innovation through knowledge inflows from headquarters and peer subsidiaries. Journal of International Management, 26(4), 1-16.

Croissant, Y., \& Millo, J. (2008). Panel Data Econometrics in R: The plm Package. Journal of Statistical Software, 27(2), 1-43.

Dosi, G. (1982). Technological paradigms and technological trajectories: A suggested interpretation of the determinants and directions of technical change. Research Policy, 11(3), 147-162.
Dost, M., Badir, Y. F., Sambasivan, M., \& Umrani, W. A. (2020). Open-and-closed process innovation generation and adoption: analyzing the effects of sources of knowledge. Technology in Society, 62, 101309.

Dourado, A. L. F., Figueira, M., \& Castro, C. C. (2019). Analysis of born globals internationalization strategy and partnerships. International Journal of Strategic Business Alliances, 6(4), 217-232.

Duarte, P. C., Lamounier, W. M., \& Takamatsu, R. T. (2007, July 26-27). Modelos econométricos para dados em painel: aspectos teóricos e exemplos de aplicação à pesquisa em contabilidade e finanças. Paper presented at the $7^{\text {th }}$ Congresso USP de Controladoria e Contabilidade and $4^{\text {th }}$ Congresso USP de Iniciação Científica em Contabilidade. São Paulo, Brazil.

Dunning, J. H. (2000). The eclectic paradigm as an envelope for economic and business theories of MNE activity. International Business Review, 9(2), 163-190.

Ferraris, A., Bogers, M. L. A. M., \& Bresciani, S. (2020). Subsidiary innovation performance: balancing external knowledge sources and internal embeddedness. Journal of International Management, 26(4), 100794.

Figueiredo, P. N., Larsen, H., \& Hansen, U. E. (2020). The role of interactive learning in innovation capability building in multinational subsidiaries: A micro-level study of biotechnology in Brazil. Research Policy, 49(6), 103995.

Fu, X., Emes, D., \& Hou, J. (2021). Multinational enterprises and structural transformation in emerging and developing countries: a survey of the literature. International Business Review, 30(2), 101801.

García-Vega, M., Hofmann, P., \& Kneller, R. (2019). Multinationals and the globalization of $R \& D$. International Journal of Industrial Organization, 63(C), 583-614.

Gilbert, M., \& Hayes, C. M. (1996). Understanding the process of knowledge transfer to achieve successful technological innovation. Technovation, 16(6), 301-12. 
Granstrand, O., \& Holgersson, M. (2020). Innovation ecosystems: A conceptual review and a new definition. Technovation, 90-91, 102098.

Granstrand, O., Patel, P., \& Pavitt, K. (1998). Multitechnology corporations: why they have distributed rather than distinctive competencies. California Management Review, 39(4).

Grant, R, M. (1996). Toward a knowledge-based theory of the firm. Strategic Management Journal, 17(S2), 109-122.

Greene, W, H. (2008). Econometric Analysis (6 $6^{\text {th }}$ ed.). New Jersey: Pearson Prentice Hall.

Gujarati, D. (2012). Econometrics by example. London: Palgrave MacMillan.

Gulati, R. (1999). Network location and learning: the influence of network resources and firm capabilities on alliance formation. Strategic Management Journal, 20(5), 397-420.

Ha, Y., J. (2021). Attention green aliens? Activities of multinational enterprises in host countries and eco-innovation diffusion. Journal of Business Research, 123(C), 32-43.

Hansen, U. E., Larsen, T. H., Bhasin, S., Burgers, R., \& Larsen, H. (2020). Innovation capability building in subsidiaries of multinational companies in emerging economies: insights from the wind turbine industry. Journal of Cleaner Production, 244, 118746.

Hossain, M. (2021). Frugal innovation and sustainable business models. Technology in Society, 64, 101508.

Howard, P. H. (2009). Visualizing consolidation in the global seed industry: 1996-2008. Sustainability, 1(4), 1266-1287.

lammarino, S., \& McCann, P. (2013). Multinationals and economic geography: location technology, and innovation. Cheltenham: Edward Elgar.

Inkpen, A. C., \& Dinur, A. (1998). Knowledge management processes and international joint ventures. Organization Science, 9(4), 454-68.
Kmenta, J. (1971). Elements of econometrics. New York: MacMillan.

Knight, G., \& Cavusgil, S.T. (2009). Born global firms: a new international enterprise. New York: Business Expert Press.

Kurth, T., Möller, C., Jerratsch, J. Adolphs, B., Wübbels, G., \& Walker, D. (2020). Reviving agricultural innovation in seeds and crop protection. Retrieved April 30, 2021, from https://www.bcg.com/publications/2020/revivingagricultural-innovation-seeds-crop-protection.

Landry, R., \& Amara, N. (2012). Elucidation and enhancement of knowledge and technology transfer business models. Journal of Information and Knowledge Management Systems, 42(1), 94-116.

Manogna, R. L., Mishra, A. K., \& Sinha, A. K. (2020). Does institutional ownership affect firms' international investments? Empirical evidence from India. Journal of Strategy and Management, 14(1), 50-63.

McBeath A., \& Ball, P. (2012). Towards a framework for transferring technology knowledge between facilities. Strategic Outsourcing: an International Journal, 5(3), 213-231.

Medasea, S. K., \& Abdul-Basit, S. (2020). External knowledge modes and firm-level innovation performance: empirical evidence from sub-Saharan Africa. Journal of Innovation \& Knowledge, 5(2), 8195.

Montagu, M. Van. (2020). The future of plant biotechnology in a globalized and environmentally endangered world. Genetics and Molecular Biology, 43(1), 1-11.

Mudambi, N, P. (2004). Is knowledge power? Knowledge flows, subsidiary power and rent-seeking within MNEs. Journal of International Business Studies, 35(5), 385-406.

Nagaoka, S., Motohashi, K., \& Goto, A. (2010). Patent statistics as an innovation indicator. In B. $\mathrm{H}$. Hall \& N. Rosenberg (Eds.), Handbook of the Economics of Innovation, vol. 2 ( $1^{\text {st }}$ ed., pp. 10831127), Amsterdam: Elsevier. 
Nelson, R., \& Winter, S. (2005). Uma teoria evolucionária da mudança econômica. Campinas: Editora da Unicamp.

Neves, P. C., Afonso, O., Silva, D., \& Sochirca, E. (2021). The link between intellectual property rights, innovation, and growth: A meta-analysis. Economic Modelling, 97, 196-209.

Organization for Economic Cooperation and Development. (2005). Oslo Manual: the measurement of scientific and technological activities. Proposed guidelines for collecting and interpreting technological innovation data. ( $3^{\text {rd }}$ ed.). Paris: OECD, Eurostat.

Papanastassiou, M., Pearce, R., \& Zanfei, A. (2020). Changing perspectives on the internationalization of R\&D and innovation by multinational enterprises: A review of the literature. Journal of International Business Studies, 51(4), 623664.

Paswan, A. K, \& Panda, S. (2020). B-to-B relationships: a resource, knowledge, and capability (RKC) perspective. Industrial Marketing Management, 91(5), 92-99.

Pereira, C. G., Da Silva, R. R., Lavoie, J.R., Porto, G.S. (2018). Technological cooperation network in biotechnology. Analysis of patents with Brazil as the priority country. Innovation \& Management Review, 15(4), 416-434.

Phene, A., Almeida, P. (2003). How do firms evolve? The patterns of technological evolution of semiconductor subsidiaries. International Business Review, 12(3), 349-367.

Phene, A., \& Almeida, P. (2008). Innovation in multinational subsidiaries: The role of knowledge assimilation and subsidiary capabilities. Journal of International Business Studies, 39(5), 901-919.

Powell, W., \& Grodal, S. (2006). Networks of innovators. In J. Fegerberg, D. C. Mowery, R. R. Nelson (Eds.), The Oxford Handbook of Innovation, (pp. 56-85), Oxford: Oxford University Press.
Ritala, P., \& Stefan, I. (2021). A paradox within the paradox of openness: the knowledge leveraging conundrum in open innovation. Industrial Marketing Management, 93(2), 281-292.

Rodrigues, L. (2018). Fusões e aquisições recentes no agronegócio preocupam produtor brasileiro. Retrieved January 30, 2021, from https://www.correiobraziliense.com.br/app/noticia/ economia/2018/04/27/internas economia,676657/ por-que-produtores-se-preocupam-com-fusoes-eaquisicoes-no- agronegocio.shtml.

Scott-Kennel, J., \& Saittakari, I. (2020). Sourcing or sharing in MNE networks? National headquarters and foreign subsidiaries as knowledge conduits in SMOPECs. International Business Review, 29(1), 101622.

Sharma, D. D., \& Blomstermo, A. (2003). The internationalization process of born globals: a network view. International Business Review, 12(6), 739-753.

Sierotowicz, T. (2015). Patent activity as an effect of the research and development of the business enterprise sectors in the countries of the European Union. Journal of International Studies, 8(2), 101113.

Silveira, R. (2018). Como fica o mercado com a fusão Bayer e Monsanto? Retrieved July 21, 2018, from

https://canalrural.uol.com.br/programas/como-ficamercado-com-fusao-bayer-monsanto-72672/.

Silveira, J. M. F. J, Dal Poz, M. E., Massago, F. K., \& Campos, R. (2011). Caracterização da trajetória tecnológica da biotecnologia agrícola por meio de redes de patentes. Revista Gestão e Políticas Públicas, 1(2), 163-187.

Singh, D. A., \& Gaur, A. S. (2013). Governance Structure, Innovation and Internationalization: Evidence from India. Journal of International Management, 19, 300-309.

Su, C., Kong, L., Ciabuschi, F., \& Yan, H. (2021). Reverse innovation transfer in Chinese MNCs: The role of political ties and headquarters. Journal of International Management, 27(1), 100829. 
Tidd, J., Bessant, J., \& Pavitt, K. (2005). Managing innovation, integration technological, market and organizational change. West Sussex: John Wiley \& Sons.

Un, C. A., \& Rodríguez, A. (2018). Local and global knowledge complementarity: R\&D collaborations and innovation of foreign and domestic firms. Journal of International Management, 24(2), 137-152.

Wooldridge, J, M. (2011). Introdução à econometria: uma abordagem moderna. São Paulo: Cengage Learning.
World Intelectual Property Report. (2019). Plant biotechnology connecting urban innovation and rural application. Retrieved January 15, 2021, from https://www.wipo.int/edocs/pubdocs/en/wipo pub 944 2019-chapter4.pdf

Zhang, F., Jiang, G., \& Cantwell, J. A. (2019). Geographically dispersed technological capability building and MNC innovative performance: the role of intra-firm flows of newly absorbed knowledge. Journal of International Management, 25(3), 100669.

\section{ABOUT THE AUTHORS}

Fernanda Teixeira Franco Ribeiro - Universidade Federal de Lavras - UFLA, Minas Gerias, (Brasil). Email: fernandafrancoribeiro@gmail.com Orcid id: https://orcid.org/0000-0002-9951-3898

Mariane Figueira - Universidade Federal de Lavras - UFLA, Minas Gerias, (Brasil). Email: mariane.fiqueira@gmail.com Orcid id: https://orcid.org/0000-0003-4680-5608

Cristina Lelis Leal Calegario - Universidade Federal de Lavras - UFLA, Minas Gerias, (Brasil). Email: cristinacalegario@gmail.com Orcid id: https://orcid.org/0000-0003-2579-8744 


\title{
O PAPEL DO CONHECIMENTO EXTERNO NAS ATIVIDADES INOVADORAS DE MULTINACIONAIS DA ÁREA DA BIOTECNOLOGIA AGRÍCOLA
}

\author{
Fernanda Teixeira Franco Ribeiro, Mariane Figueira, Cristina Lelis Leal Calegario \\ Universidade Federal de Lavras - UFLA, Minas Gerias, (Brasil)
}

\begin{tabular}{l} 
DETALHES DO ARTIGO \\
\hline Histórico do Artigo: \\
Recebido: 21 de Maio de 2020 \\
Aceito: 07 de Julho de 2021 \\
Disponível online: 01 de Setembro de \\
2021 \\
Sistema de revisão “Double blind review” \\
Editor Científico \\
Ilan Avrichir \\
\hline Palavras-chaves: \\
Inovação \\
Patentes \\
Empresas multinacionais \\
Escala inovativa
\end{tabular}

\section{RESUMO}

Objetivo: Avaliar a influência do conhecimento externo absorvido sobre o potencial inovador das empresas multinacionais (EMNs), do setor de sementes geneticamente modificadas (GM) de 2000 a 2018.

Método: Uma abordagem quantitativa foi aplicada. Os dados foram compostos pelas principais patentes depositadas por EMNs no setor de sementes GM, coletadas da base Espacenet, dos relatórios anuais das EMNs e da base do INPI. As variáveis foram analisadas por meio de modelo de regressão em painel.

Principais resultados: Os resultados mostraram que os recursos próprios das EMNs, bem como o conhecimento externo absorvido, foram individualmente significativos. A variável interativa não foi significativa no modelo.

Relevância/originalidade: Além de abordar lacunas da literatura relacionadas à necessidade de investigar os fatores que influenciam a inovação nas multinacionais, esse estudo teve como foco o setor de biotecnologia agrícola, de suma importância para as inovações geradas na agricultura.

Contribuições teóricas: Este estudo contribui preenchendo lacunas da literatura relacionadas à necessidade de compreender o quão importante é a influência do conhecimento e recursos externos para as capacidades inovativas das EMNs.

Contribuições sociais: Este artigo ajuda os gestores a terem consciência de que a inovação não se desenvolve apenas internamente, envolvendo a própria rede da multinacional, mas, de fato, a inovação requer o relacionamento com outras empresas, permitindo o acesso a conhecimentos e recursos externos. 


\title{
EL PAPEL DEL CONOCIMIENTO EXTERNO EN LAS ACTIVIDADES INNOVADORAS DE LAS MULTINACIONALES EN EL ÁREA DE LA BIOTECNOLOGÍA AGRÍCOLA
}

\author{
Fernanda Teixeira Franco Ribeiro, Mariane Figueira, Cristina Lelis Leal Calegario \\ Universidade Federal de Lavras - UFLA, Minas Gerias, (Brasil)
}

\begin{tabular}{|c|c|}
\hline DETALLES DEL ARTÍCULO & RESUMEN \\
\hline $\begin{array}{l}\text { Historia del Artículo: } \\
\text { Recibido: } 21 \text { Mayo } 2020 \\
\text { Aceptado: } 07 \text { Julio } 2021 \\
\text { Disponible en línea: } 01 \text { de Septiembre } \\
\text { de } 2021 \\
\text { Double Blind Review System } \\
\text { Editor Científico } \\
\text { Ilan Avrichir }\end{array}$ & $\begin{array}{l}\text { Objetivo del estudio: Evaluar la influencia del conocimiento externo } \\
\text { absorbido sobre el potencial de innovación de las empresas } \\
\text { multinacionales (EMNs), en el sector de semillas genéticamente } \\
\text { modificadas (GM) de } 2000 \text { a } 2018 \text {. } \\
\text { Metodología: Se aplicó un enfoque cuantitativo. Los datos se componen } \\
\text { de las principales patentes presentadas por las EMNs del sector de semillas } \\
\text { GM, recogidas de la base de datos Espacenet, los informes anuales de las } \\
\text { EMNs y la base de datos INPI. Las variables se analizaron mediante un } \\
\text { modelo de regresión de panel. } \\
\text { Originalidad/ relevancia: Además de abordar los vacíos en la literatura } \\
\text { relacionados con la necesidad de investigar los factores que influyen en la } \\
\text { generación de innovación en las multinacionales y el hecho de que la } \\
\text { innovación en estas empresas implica el acceso al conocimiento interno y } \\
\text { externo, el presente estudio se centró en el sector de la biotecnología } \\
\text { agrícola, lo cual es de suma importancia para las innovaciones generadas } \\
\text { en la agricultura. } \\
\text { Resultados: Los resultados mostraron que los recursos propios de las } \\
\text { empresas multinacionales, así como el conocimiento externo absorbido, } \\
\text { eran individualmente significativos. La variable Interactiva no fue } \\
\text { significativa en el modelo. } \\
\text { Contribuciones teóricas: Este estudio contribuye a llenar los vacíos de la } \\
\text { literatura relacionados con la necesidad de comprender cuán importante } \\
\text { es la influencia del conocimiento y los recursos externos en las } \\
\text { capacidades innovadoras de las empresas multinacionales. } \\
\text { Contribuciones sociales: Este trabajo ayuda a los gerentes a ser } \\
\text { involucrando a la propia red de la EMN, sino que, de hecho, la innovación } \\
\text { requiere relaciones con otras empresas, permitiendo el acceso de } \\
\text { conocimientos y recursos externos. }\end{array}$ \\
\hline
\end{tabular}

\section{How to cite this article}

Ribeiro, F. T. F., Figueira, M., \& Calegario, C. L. L. (2021). The Role of External Knowledge in the Innovative Activities of Agricultural Biotechnology Multinationals. Internext, 16(3), 271-288. https://doi.org/10.18568/internext.v16i3.610 